\title{
The Effect of Ethylenediaminetetra-acetic Acid on the Cell Walls of Some Gram-Negative Bacteria
}

\author{
By G. W. GRAY AND S. G. WILKINSON \\ Department of Chemistry, University of Hull
}

(Received 17 February 1965)

\begin{abstract}
SUMMARY
A comparative survey of amino acid, amino sugar, sugar and lipid components of the cell walls of strains of Pseudomonas aeruginosa, Alcaligenes faecalis, Escherichia coli and Proteus mirabilis was made. The cell walls of $\boldsymbol{P}$. aeruginosa and $\boldsymbol{A}$. faecalis, against which ethylenediaminetetra-acetic acid (EDTA) has a potent bactericidal action, differed from those of the other organisms principally in their sugar components and in their high content of phosphorus. EDTA at alkaline $\mathrm{pH}$ selectively solubilized a high proportion of the carbohydrate and phosphorus present, apparently as lipopolysaccharides, in the walls of sensitive organisms. It is suggested that metal cations and lipopolysaccharides in the cell walls of $\boldsymbol{P}$. aeruginosa and $\boldsymbol{A}$. faecalis may be essential to the structural integrity of these organisms.
\end{abstract}

\section{INTRODUCTION}

The ability of ethylenediaminetetra-acetic acid (EDTA) to sensitize certain Gram-negative bacteria to lysozyme was shown by Repaske (1956), who suggested (1958) that EDTA removed or combined with metal ions which were bound by the cell wall and which interfered with the formation of the lysozyme-substrate complex. This view was supported by the similar ability of the cation-exchange resin Dowex $50\left(\mathrm{H}^{+}\right)$to sensitize bacteria to lysozyme and by the inhibition of lysis of sensitized bacteria by metal ions. Other workers (e.g. Salton, 1958; Noller \& Hartsell, $1961 a, b$ ) considered that EDTA disorganized one of the layers, probably lipoprotein, which overlie and protect the mucopeptide substrate of lysozyme in the cell walls of Gram-negative bacteria (Weidel, Frank \& Martin, 1960). Thus, the purified mucopeptides of these bacteria were completely dissolved by lysozyme without the addition of EDTA (Weidel et al. 1960; Mandelstam, 1962). In the cases of various pathogenic Salmonella organisms, the action of EDTA in making the mucopeptide accessible to lysozyme was found (Colobert, $1957 a, b$ ) to involve the release of lipid material, believed to come from the $O$ antigens of the cell walls. Treatment with EDTA was used by Colobert \& Creach (1960) as a step in the purification of the mucopeptide from Salmonella typhi. The action of EDTA was thought by Colobert (1958) and Noller \& Hartsell $(1961 a, b)$ to involve a detergent-like mechanism rather than a chelating mechanism. However, the technical bulletin quoted by Grula \& Hartsell (1957) and Colobert (1958) refers only to the ability of solutions of the tetrasodium salt of EDTA to dissolve grease. This property is a function of the alkalinity and buffering capacity of concentrated solutions of the salt and would not apply with the low concentrations of EDTA in buffer of about $\mathrm{pH} 8$ used in potentiation of lysozyme action. 
In a previous paper (Gray \& Wilkinson, 1965), it was shown that EDTA had a lytic bactericidal action on Pseudomonas aeruginosa and Alcaligenes faecalis. Evidence was obtained that the bactericidal action took place at the cell wall and involved the removal or displacement of metal ions essential to the structural integrity of the wall. Such a function was suggested for calcium ions in the cell wall of Rhizobium trifolii (Humphrey \& Vincent, 1962; Vincent \& Humphrey, 1963). If metal ions are structural components in bacterial cell walls, then the sensitivity of an organism to EDTA should be dependent on the nature and strength of the bonds formed between the metal and the metal-binding components of the cell wall. Thus, the chemical basis for the exceptional sensitivity to EDTA of $\boldsymbol{P}$. aeruginosa and $A$. faecalis might be indicated by a study of the composition of their cell walls. The present paper records the results of a survey of the cell walls from organisms of various degrees of sensitivity to EDTA. The highly sensitive organisms $P$. aeruginosa and $\boldsymbol{A}$. faecalis, the moderately sensitive Escherichia coli and the insensitive Proteus mirabilis were chosen for this survey (Gray \& Wilkinson, 1965).

\section{METHODS}

Organisms and preparation of cell walls. Cultures of single strains of Pseudomonas aeruginosa, Alcaligenes faecalis, Escherichia coli and Proteus mirabilis were grown and the cell walls of the organisms were isolated from the strains and by the methods previously described (Gray \& Wilkinson, 1965). The freeze-dried wall preparations were stored at $4^{\circ}$ and were freshly dried $\left(\mathrm{P}_{2} \mathrm{O}_{5}\right)$ in vacuo before being analysed.

Purity of cell-wall preparations. The absence of significant cytoplasmic contamination of the preparations was indicated by the absence of electron-dense material in electron micrographs, and by the failure to detect ribose in acid hydrolysates of the cell walls. The ultraviolet spectra of aqueous suspensions of the walls showed a minor peak or inflexion at 275-280 $\mathrm{m} \mu$ but no absorption maximum at $260 \mathrm{~m} \mu$, confirming the absence of polynucleotides. The consistency $( \pm 2 \%$ ) of analyses for phosphorus and carbohydrate and the results of quantitative evaluations of infrared spectra of different batches of walls from each organism confirmed that reproducible preparations were obtained.

Quantitative analyses. Phosphorus was estimated by the method of Allen (1940), and nitrogen by a modification of the method of Umbreit, Burris \& Stauffer (1957). Estimations of reducing sugar (Hanes, 1929), carbohydrate (Trevelyan \& Harrison, 1952 ) and amino sugar (Rondle \& Morgan, 1955) were made on samples of filtered neutralized hydrolysates $\left(2 \mathrm{~N}-\mathrm{HCl}\right.$ for $2 \mathrm{hr}$ at $\left.105^{\circ}\right)$ of the cell walls.

Identification of amino acids. Hydrolysates $\left(6 \mathrm{~N}-\mathrm{HCl}\right.$ for $16 \mathrm{hr}$ at $\left.105^{\circ}\right)$ of cell walls were examined by two-dimensional chromatography by using Whatman no. 1 paper and $s e c$-butanol $+88 \%$ formic acid + water $(75+15+10$, by vol.) followed by phenol +water $+5 \mathrm{~N}$-ammonia $(80+20+0 \cdot 3$, by wt.). Spots were detected by means of ninhydrin. The identity of sulphur-containing acids was checked by using samples of hydrolysates treated with hydrogen peroxide followed by chromatography as above. The presence of diaminopimelic acid in hydrolysates was confirmed by descending chromatography using as solvent a mixture of methanol + water $+10 \mathrm{~N}$-hydrochloric acid + pyridine $(32+7+1+4$, by vol.; Rhuland, Work, Denman \& Hoare, 1955). 
Identification of amino sugars. Hydrolysates of cell walls were prepared as for the identification of amino acids and were examined by two-dimensional paper chromatography with solvents pyridine + water $(4+1$, by vol.) followed by $n$-butanol + acetic acid + water $(6+1+2$, by vol.; Salton \& Pavlik, 1960), and also by onedimensional chromatography with solvent pyridine + ethyl acetate + water + acetic acid $(5+5+3+1$, by vol.; Fischer \& Nebel, 1955). Spots on replicate papers were detected by means of ninhydrin, alkaline silver nitrate and the Elson-Morgan reagents. Confirmatory evidence for the presence in hydrolysates of glucosamine and galactosamine was obtained by the method of Stoffyn \& Jeanloz (1954). After partial separation by chromatography with $n$-butanol + ethanol + water $(4+1+1$, by vol.), the amino sugars were degraded by ninhydrin to the corresponding pentoses, which were separated by further chromatography with the above solvent and detected by aniline phthalate reagent.

Identification of sugars. Samples of cell walls were hydrolysed with $2 \mathrm{~N}-\mathrm{H}_{2} \mathrm{SO}_{4}$ for $2 \mathrm{hr}$ at $105^{\circ}$. After neutralization of acid by $\mathrm{Ba}(\mathrm{OH})_{2}$ and removal of insoluble materials, the hydrolysates were examined by one-dimensional chromatography on Whatman no. 1 paper with the following solvents: the upper layer of ethyl acetate + pyridine + water $(5+2+5$, by vol.; Jermyn \& Isherwood, 1949); isopropanol + water $(4+1$, by vol.); phenol + water $(4+1$, by wt.). Spots were detected by the aniline phthalate and silver nitrate reagents. The Dische reaction for the detection of aldoheptoses (Dische, 1953) was applied to samples of unhydrolysed cell walls following the method of Salton (1960). After 24 hr, the visible spectra of the solutions were obtained by using a Unicam SP. 500 spectrophotometer. In cases where the presence of aldoheptoses was indicated by this test, samples of hydrolysates were chromatographed and the Dische reaction was applied to solutions of the sugars eluted from chromatograms.

Extraction of lipids. Insufficient amounts of materials were available to permit a study of the effectiveness of different extraction procedures. The method adopted for the extraction of free and loosely bound lipids of the cell walls was that used by Few (1955). Samples of the cell walls were heated under reflux for $1 \mathrm{hr}$ with 20 parts $(\mathrm{v} / \mathrm{w})$ of $95 \%(\mathrm{v} / \mathrm{v})$ methanol in water to disrupt lipoprotein complexes. The methanol was removed under reduced pressure and the cell walls were dried $\left(\mathrm{P}_{2} \mathrm{O}_{5}\right)$ for $3 \mathrm{hr}$ in vacuo. The lipids were then extracted by heating under reflux with diethyl ether $(5 \mathrm{ml}$.) for $\mathbf{3 0} \mathrm{min}$. Like all the solvents used, the ether was AnalaR grade, freshly dried and distilled. Three repetitions of the extraction removed all ether-soluble materials. The combined extracts were passed through a sinteredglass filter (no. 4 porosity) into a tared weighing bottle, the ether was removed by blowing a stream of nitrogen over the surface, and the residue weighed after drying $\left(\mathrm{P}_{2} \mathrm{O}_{5}\right)$ overnight in vacuo. The lipids (pale yellow greases) were completely soluble in chloroform + methanol $(2+1$, by vol.), in which they were dissolved for storage at $4^{\circ}$.

For comparative purposes, the lipids from one batch of cell walls of Pseudomonas aeruginosa were extracted with chloroform + methanol $(2+1$, by vol. $)$. The cell walls (180 mg.) were vigorously stirred with solvent $(15 \mathrm{ml}$.) for $1 \mathrm{hr}$ at room temperature. The insoluble residue was collected and washed on a sintered glass filter (no. 4 porosity), and the washings $(30 \mathrm{ml}$.) were added to the filtrate. The extracted lipids were recovered as described above. 
Analysis of lipids. Analytical studies were restricted by the small amounts (normally 10-15 mg.) of lipids from individual batches of cell walls. Estimations of phosphorus and nitrogen were made by the methods indicated above, and ester groups were determined by the method of Rapport \& Alonzo (1955), with methyl palmitate (over $99 \%$ pure) as reference standard. A qualitative test for plasmalogens in lipid samples (about $1 \mathrm{mg}$.) was made by the method of Gray \& Macfarlane (1958). Hydrolysates of lipids were prepared and examined by paper chromatography for the presence of amino acids, sugars and polyols (including inositol); papers run with $n$-butanol+diethyleneglycol + water $(4+1+1$, by vol.) were examined for choline by the phosphomolybdic acid method of Levine \& Chargaff (1951). Samples (1-2 mg.) of the lipids were fractionated on silicic acid on the day following their extraction by the micro method of Lis, Tinocq \& Okey (1961). The composition of whole lipids and lipid fractions was indicated by infrared spectroscopy.

Infrared spectra. Spectra were recorded on a Unicam SP. 100 double-beam spectrophotometer, with the specimens (cell walls or lipids) dispersed in discs of anhydrous potassium bromide.

Extraction of cell walls with EDTA. Samples of suspensions of cell walls (about $4 \mathrm{mg} . / \mathrm{ml}$.) in ion-depleted water were mixed with equal volumes of $0.0068 \mathrm{M}$-EDTA in $0.05 \mathrm{M}$-borate buffer ( $\mathrm{pH} \mathrm{9.2)}$ ) or with borate buffer alone (Gray \& Wilkinson, 1965). After $1 \mathrm{hr}$ at $18-20^{\circ}$, the suspensions were centrifuged for $1 \mathrm{hr}$ at 10,000 rev./ min. and the supernatant fluids carefully withdrawn. The deposits of cell-wall residues were washed twice with ion-depleted water, freeze-dried, and their infrared spectra recorded. Samples of the supernatant fluids from the extractions were analysed for phosphorus and for carbohydrate (anthrone method). Estimates for the amounts of wall protein (containing aromatic amino acids) in the fluids were obtained by measurement of their absorptions at $275 \mathrm{~m} \mu$ and comparing them with the values for whole wall suspensions. Corrections were applied for the absorption of EDTA when present.

\section{RESULTS}

\section{Components of bacterial cell walls}

Amino acids. As expected, acid hydrolysates of the cell walls from the four Gram-negative organisms studied contained a wide range of amino acids characteristic of proteins, as well as the mucopeptide component diaminopimelic acid. The range of amino acids and the relative amounts of each (assessed by visual examination of chromatograms) were similar for each organism. Alanine, glutamic acid and aspartic acid were present in the largest amounts, while the following acids were also identified: diaminopimelic acid, serine, glycine, threonine, lysine, arginine, tyrosine, phenylalanine, proline, valine, methionine, methionine sulphoxide, leucine/isoleucine, and cysteic acid (traces only). Hexosamines and ethanolamine were detected simultaneously. Allowing for the contributions by lipid and mucopeptide components to nitrogen analyses, the results in Table 1 indicate that the cell walls of these organisms contain about $\mathbf{4 0 - 5 0 \%}$ of protein which resisted digestion by trypsin.

Amino sugars. The amino sugars identified in hydrolysates of the cell walls are shown in Table 2; values for total amino sugar contents are given in Table 1. In all 
four cases, glucosamine was the most abundant amino sugar, while the greatest amount of galactosamine was in the walls from Proteus mirabilis. The low analyses for amino sugars are consistent with the low mucopeptide contents of the walls of Gram-negative organisms (Mandelstam, 1962).

Table 1. Analyses of cell walls of some Gram-negative bacteria

\begin{tabular}{|c|c|c|c|c|c|}
\hline & $\begin{array}{c}\text { Phosphorus } \\
(\%)\end{array}$ & $\begin{array}{l}\text { Nitrogen } \\
(\%)\end{array}$ & $\begin{array}{c}\text { Reducing } \\
\text { sugar* } \\
(\%)\end{array}$ & $\begin{array}{c}\text { Anthrone } \\
\text { sugar* } \\
(\%)\end{array}$ & $\begin{array}{c}\text { Amino } \\
\text { sugar† } \\
(\%)\end{array}$ \\
\hline Pseudomonas aeruginosa & $\mathbf{2 \cdot 3}$ & $7 \cdot 7$ & $18 \cdot 1$ & $6 \cdot 7$ & $\mathbf{3} \cdot \mathbf{9}$ \\
\hline Alcaligenes faecalis & $\mathbf{2 \cdot 3}$ & $8 \cdot 5$ & $15 \cdot 2$ & $3 \cdot 8$ & $\mathbf{3 \cdot 7}$ \\
\hline Escherichia coli & 1.5 & $9 \cdot 5$ & $19 \cdot 1$ & $4 \cdot 4$ & $4 \cdot 3$ \\
\hline Proteus mirabilis & 0.95 & $8 \cdot 8$ & $20 \cdot 8$ & $4 \cdot 0$ & $\mathbf{3} \cdot \mathbf{3}$ \\
\hline
\end{tabular}

Table 2. Sugar and amino sugar components of cell walls of some Gram-negative bacteria

\begin{tabular}{|c|c|c|c|c|c|c|c|}
\hline & 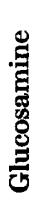 & 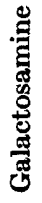 & 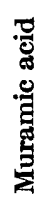 & 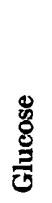 & 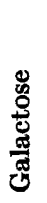 & 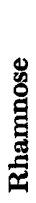 & 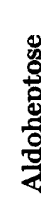 \\
\hline Pseudomonas aeruginosa & + & + & + & + & - & + & - \\
\hline Alcaligenes faecalis & + & + & + & + & - & + & $?$ \\
\hline Escherichia coli & + & - & + & + & + & - & ? \\
\hline Proteus mirabilis & + & + & + & + & + & - & 1 \\
\hline
\end{tabular}

Sugars. Table 2 indicates the neutral sugars which were identified as components of the cell walls. Except for aldoheptoses and the components of the walls of Proteus mirabilis, the sugars were readily identified chromatographically. In the case of $\boldsymbol{P}$. mirabilis, a diffuse elongated spot covering the region corresponding to glucose and galactose was obtained. As aldoheptoses have similar $\boldsymbol{R}_{F}$ values, further information was sought by using the specific Dische reaction. The spectrum obtained from the unhydrolysed cell walls showed a pronounced absorption maximum at about $510 \mathrm{~m} \mu$, diagnostic for aldoheptoses. Similar spectra (Fig. 1) from reactions carried out on materials eluted from chromatograms confirmed this identification and also indicated the presence in the same region of the paper of glucose and galactose (absorption maxima at 4110 and $390 \mathrm{~m} \mu$ respectively). The application of the Dische reaction to the cell walls of the other organisms confirmed the chromatographic results and suggested the possible presence of aldoheptoses in the walls from Alcaligenes faecalis and Escherichia coli; however this was not satisfactorily confirmed by reactions with eluted materials.

Estimates of the reducing sugar and neutral sugar (anthrone method) contents of acid hydrolysates of the cell walls are given in Table 1 . The values for reducing sugars (which include amino sugars) are likely to be overestimates (Salton \& Pavlik, 1960), while those obtained by the anthrone method would be depressed by the low colour yields from galactose and rhamnose relative to that from glucose. Confirming the order of the anthrone results, inspection of paper chromatograms 
suggested that the walls from Pseudomonas aeruginosa have the highest and those from Alcaligenes faecalis the lowest content of neutral sugars among the four organisms examined.

Lipids. As noted by Wardlaw (1963) and Herzberg \& Green (1964), appreciable quantitative variation in lipid content and composition was found (Table 3) for different batches of cell walls from each organism. However, preliminary studies indicated that the lipids from all four organisms were broadly similar in composition. The analyses for lipid phosphorus indicated that lipids other than phospholipids were present in all cases. Fractionation of the lipids on silicic acid followed by infrared spectroscopic examination of the fractions showed that in every case only

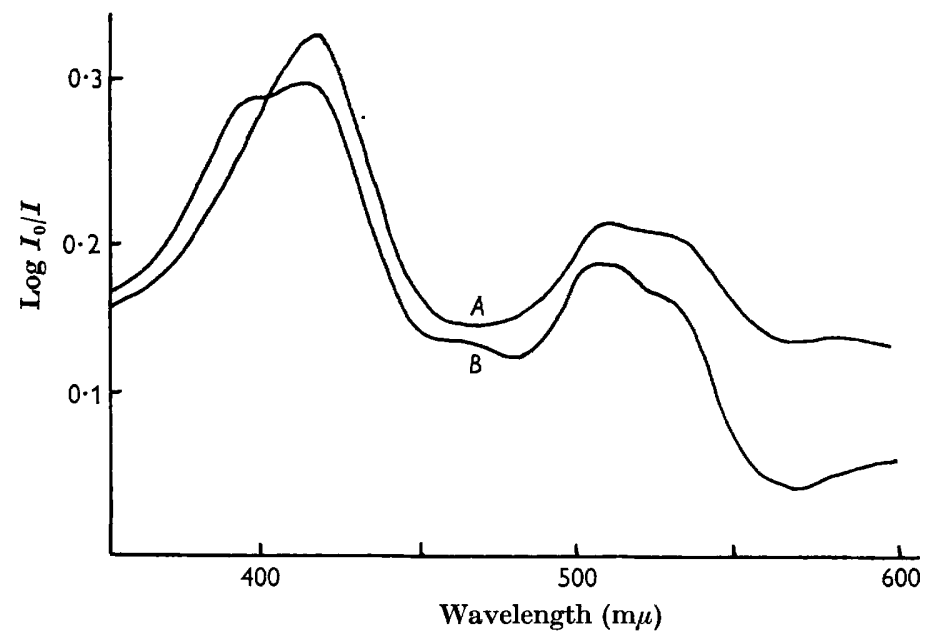

Fig. 1. Spectra of Dische reaction products of sugars from cell walls of Proteus mirabilis. The reaction was applied to fractions obtained by paper chromatography of hydrolysed walls (10 mg.). $A$, 'Glucose' fraction; $B$, 'galactose' fraction.

Table 3. Readily extractable lipids of cell walls of some Gram-negative bacteria

\begin{tabular}{|c|c|c|c|c|c|}
\hline & \multicolumn{3}{|c|}{ Pseudomonas aeruginosa } & \multicolumn{2}{|c|}{ Alcaligenes faecalis } \\
\hline & Batch 1 & Batch 2 & Batch 3* & Batch 1 & Batch 2 \\
\hline Lipid (\%) & $5 \cdot 3$ & $9 \cdot 3$ & $10 \cdot 0$ & $14 \cdot 2$ & $9 \cdot 5$ \\
\hline $\mathbf{P}$ in lipid $(\%)$ & $2 \cdot 1$ & $\mathbf{2 \cdot 5}$ & $\mathbf{2 \cdot 2}$ & 0.73 & $\mathbf{1 \cdot 2}$ \\
\hline $\mathbf{N}$ in lipid (\%) & 0.75 & $c .1$ & $1 \cdot 1$ & 0.51 & $0 \cdot 65$ \\
\hline Ratio P:N & $1 \cdot 25$ & $c .1 \cdot 1$ & $0 \cdot 9$ & $0 \cdot 65$ & $0 \cdot 84$ \\
\hline \multirow[t]{3}{*}{ Ratio ester: $\mathbf{P}$} & $2 \cdot 0$ & 1.9 & $\mathbf{2 \cdot 0}$ & $2 \cdot 1$ & $2 \cdot 0$ \\
\hline & \multicolumn{3}{|c|}{ Escherichia coli } & \multicolumn{2}{|c|}{ Proteus mirabilis } \\
\hline & Batch I & Batch 2 & & Batch 1 & Batch 2 \\
\hline Lipid (\%) & $5 \cdot 8$ & $5 \cdot 8$ & & $10 \cdot 1$ & $8 \cdot 0$ \\
\hline $\mathbf{P}$ in lipid (\%) & $1 \cdot 87$ & $3 \cdot 14$ & & $0 \cdot 48$ & $1 \cdot 5$ \\
\hline $\mathrm{N}$ in lipid (\%) & 0.78 & $1 \cdot 2$ & & 0.21 & $0 \cdot 62$ \\
\hline Ratio $\mathbf{P}: \mathbf{N}$ & $1 \cdot \mathbf{1}$ & $1 \cdot 2$ & & $1 \cdot 0$ & $1 \cdot 1$ \\
\hline Ratio ester: $\mathbf{P}$ & $1 \cdot 9$ & $1 \cdot 8$ & & $2 \cdot 2$ & $1 \cdot 7$ \\
\hline
\end{tabular}

* Lipids were extracted from this batch by chloroform + methanol $(2+1$, by vol. $)$. A further $\mathbf{9 . 3} \%$ (expressed as \% of the original walls) of fatty material was extracted by ether from an acid hydrolysate (Salton, 1953) of the residual wall material. 
phospholipids and free fatty acids were present in large amounts. On the scale used, no detectable residues were obtained from the fractions which would have contained sterol esters and triglycerides, and neither sterols, nor monoglycerides nor diglycerides were detected in the fraction containing free fatty acids. The infrared spectra of the fatty acid fractions from Pseudomonas aeruginosa (Fig. 2) and

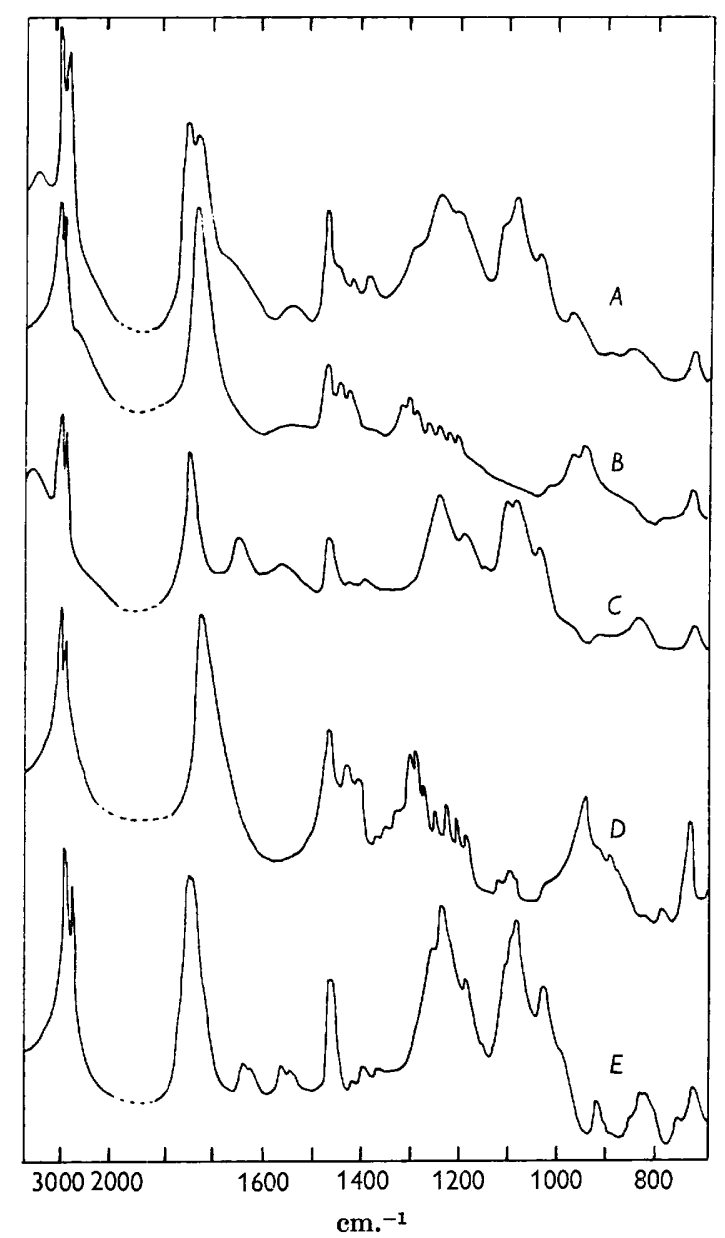

Fig. 2. Infrared spectra of lipids from cell walls of Pseudomonas aeruginosa. A, Unfractionated lipid; $B$, fatty acid fraction; $C$, phospholipid fraction; $D$, reference sample of palmitic acid; $E$, reference sample of $L-\alpha$-(dipalmitoyl)phosphatidylethanolamine.

Alcaligenes faecalis showed absorption bands at about $970 \mathrm{~cm} .^{-1}$, which may be attributed to trans-unsaturation in the component acids. This band was absent from the corresponding spectra of acids from Escherichia coli and Proteus mirabilis. Although decomposition of lipids, to give free fatty acids, during storage of the cell walls before extraction probably contributed to variability in lipid analyses, the presence of free fatty acids in the extracts cannot be entirely explained in this way, at least in the case of $P$. aeruginosa. Thus, about $50 \%$ of the lipids from each of two batches of cell walls of $\boldsymbol{P}$. aeruginosa, extracted one day after isolation by ether or by 
chloroform + methanol, consisted of free fatty acids. No detectable amount of fatty acid was liberated from a pure sample of phosphatidylethanolamine on refluxing with $95 \%(\mathrm{v} / \mathrm{v})$ methanol and then with ether as used in the standard extraction procedure. Thus the fatty acids appeared to be at least in part genuine components of the cell walls or were produced by autolytic reactions during the isolation of the walls.

The phospholipid fraction from the walls of each organism appeared to contain predominantly phosphatidylethanolamine, probably together with small amounts of phosphatidylserine. The infrared spectra of all the phospholipids resembled that of a synthetic sample of phosphatidylethanolamine (see Fig. 2 for that of the phospholipid fraction from Pseudomonas aeruginosa) and had an absorption band at $1030 \mathrm{~cm}^{-1}$, characteristic of this class of lipid (Marinetti \& Stotz, 1954). The absence of a band at $970 \mathrm{~cm} .^{-1}$ confirmed the absence of phosphatidylcholine. After acid hydrolysis of the phospholipids, choline, inositol and neutral sugars were not

Table 4. Nitrogenous components of cell-wall lipids of some Gram-negative bacteria

\begin{tabular}{llll} 
Pseudomonas aeruginosa & Alcaligenes faecalis & Escherichia coli & Proteus mirabilis \\
Ethanolamine* & Ethanolamine* & Ethanolamine* & Ethanolamine* \\
Serine* & Serine* & Serine & Serine \\
Glycine & Glycine & & Hexosamine \\
Lysine & Lysine & \\
Alanine & Alanine & \\
Leucine & Leucine & \\
Hexosamine & \multirow{2}{*}{ Major components. }
\end{tabular}

detected; ethanolamine was the major ninhydrin-positive component in all the hydrolysates. Whilst only traces of other amino compounds were found in the hydrolysate of lipid from Escherichia coli, significant amounts were found for those from the other organisms, particularly Alcaligenes faecalis (Table 4). Since glutamic and aspartic acids were detected in only small amounts and diaminopimelic acid was absent, it is unlikely that the lipid extracts were contaminated by insoluble wall material. The presence of proteo- or peptido-lipids in the phospholipid fractions from $P$. aeruginosa and $A$. faecalis would explain some of the differences (e.g. increased absorption at 1655 and $1550 \mathrm{~cm}^{-1}$, attributable to -CO.NH-) between the infrared spectra of these lipids and phosphatidylethanolamine. The origin of the component, provisionally identified as a hexosamine, in the lipid from Proteus mirabilis was not investigated.

A negative test for plasmalogens was obtained for all lipids, while the ester: phosphorus ratios of about 2:1 (Table 3) for the unfractionated lipids also indicate the essential absence of plasmalogens and lyso-phosphatides. The phosphorus: nitrogen ratios were near unity for the lipids from Escherichia coli and Proteus mirabilis, suggesting that nitrogen-free phospholipids such as cardiolipin and phosphatidylglycerol were unlikely to be major components. Although the situation with Pseudomonas aeruginosa and Alcaligenes faecalis was confused by the greater content of amino acids, further work on the lipids from $P$. aeruginosa, done in these laboratories by Mr J. W. Payne, has confirmed a similar view of these lipids. 


\section{Infrared spectra of cell walls}

Qualitatively the spectra from different cell walls were very similar (Fig. 3), and showed the absorption bands expected for proteins, carbohydrates and lipids. The relative height of the major peaks at $1655 \mathrm{~cm} .^{-1}$ and $1550 \mathrm{~cm} \cdot .^{-1}$ was virtually constant (1.5 to 1$)$, suggesting that these absorptions were almost solely due to peptide

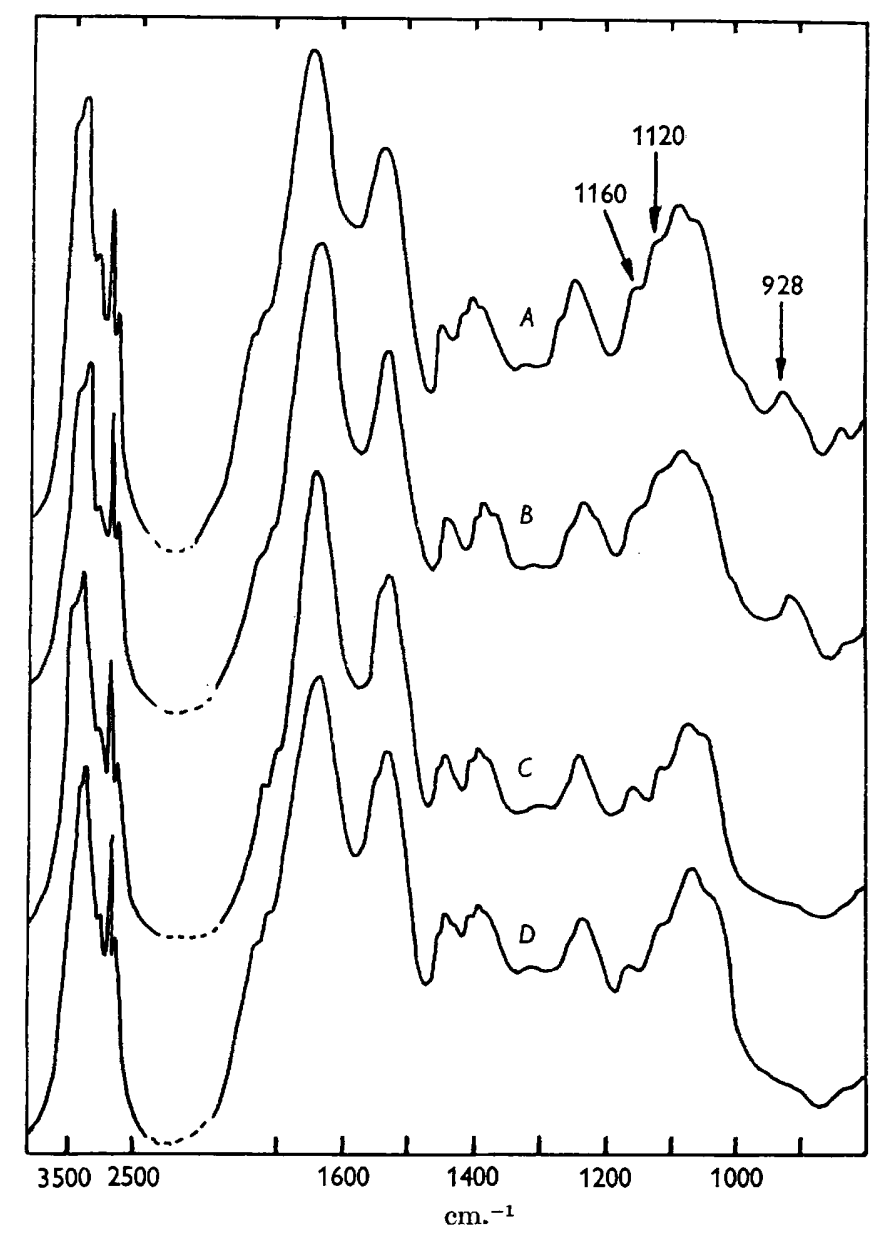

Fig. 3. Infrared spectra of bacterial cell walls. A, Pseudomonas aeruginosa; B, Alcaligenes faecalis; $C$, Escherichia coli; D, Proteus mirabilis.

bonds. By calibrating the $1655 \mathrm{~cm} .^{-1}$ peaks by reference to a spectrum of trypsin, it was estimated that the cell walls contained $50-65 \%$ of material with peptide linkages (e.g. protein, mucopeptide).

The spectra of the walls from organisms which were highly sensitive to EDTA contained a minor peak at $928 \mathrm{~cm} .^{-1}$ which was virtually absent from the other spectra. No firm assignment can be given to this absorption, although a band at $930 \mathrm{~cm} .^{-1}$ has been attributed to a ring vibration in $\alpha(1-4)$-linked polyglucosans (Stacey \& Barker, 1960). Other differences between the wall spectra of EDTA- 
sensitive and EDTA-resistant organisms were found in the region $1000-1300 \mathrm{~cm} \cdot{ }^{-1}$, particularly the height of shoulders at $1120 \mathrm{~cm} .^{-1}$ and $1160 \mathrm{~cm} .^{-1}$. Although this region of the spectrum was too complex to permit detailed interpretation, phosphate esters and carbohydrates would be expected to make major contributions to absorption in this region.

\section{Action of EDT $A$ on cell roalls}

It has been shown (Gray \& Wilkinson, 1965) that the turbidity of aqueous suspensions of the walls of Pseudomonas aeruginosa and Alcaligenes faecalis is substantially decreased (about $30 \%$ ) by $0 \cdot 0034$ m-EDTA at pH $9 \cdot 2$. After centrifuging such suspensions to deposit cell-wall residues, large proportions of the total phosphorus and carbohydrate, but not 'protein', remained in the supernatant fractions (Table 5). With both organisms, the percentage extractions of phosphorus and carbohydrate were similar, whereas the cell walls of $A$. faecalis contained appreciably less carbohydrate than those of $\boldsymbol{P}$. aeruginosa. This suggested that EDTA solubilized most or all of the above components from a fraction of the cell walls, rather than the same fraction from the walls of both organisms.

Table 5. Extraction by EDTA of cell-wall components of some Gram-negative bacteria

\begin{tabular}{|c|c|c|c|c|}
\hline \multirow{3}{*}{$\begin{array}{l}\text { Pseudomonas aeruginosa } \\
\text { Alcaligenes faecalis }\end{array}$} & \multicolumn{3}{|c|}{$\begin{array}{c}\text { Carbo- } \\
\text { Phosphorus hydrate 'Protein' } \\
\text { Extraction }(\%)^{*}\end{array}$} & \multirow{2}{*}{$\begin{array}{c}\text { Decrease in } \\
\text { turbidity } \dagger \\
(\%) \\
33\end{array}$} \\
\hline & 30 & 35 & 1 & \\
\hline & 28 & 29 & 4 & 28 \\
\hline Escherichia coli & $\mathbf{2}$ & $\mathbf{3}$ & 2 & 14 \\
\hline Proteus mirabilis & 0 & 0 & $\mathbf{0}$ & 0 \\
\hline
\end{tabular}

In one experiment with the walls of Pseudomonas aeruginosa, only $7 \%$ of the soluble phosphorus was estimated as inorganic orthophosphate. It was also shown that the solubilization of components from the walls of this organism was not an artifact caused by incubating with enzymes in the purification of the walls (the phosphorus content of the walls was increased $15 \%$ by treatment with enzymes). However, the extractability of wall components by EDTA was decreased about $\mathbf{5 0} \%$ by omission of the enzyme treatment. In the control extractions with $\mathrm{pH} \mathbf{9 \cdot 2}$ buffer alone, rather high values for soluble phosphorus (19\%) and carbohydrate $(14 \%)$, compared with 'protein' $(8 \%)$, were obtained with the walls of EDTAsensitive organisms. Although the values could be decreased by more intensive centrifugation, the differences suggested solubilization by freeze-drying (Brown, 1958) or lability to alkali of specific wall components, perhaps of the same kind as solubilized by EDTA.

The selective solubilization of wall components by EDTA was confirmed by examination of the infrared spectra of the washed insoluble wall residues (Fig. 4). With the walls from Pseudomonas aeruginosa and Alcaligenes faecalis, EDTA 
caused marked attenuation of the absorption bands in the range $1000-1300 \mathrm{~cm}^{-1}$ so that the spectra resembled much more closely those of the untreated cell walls of Escherichia coli and Proteus mirabilis (Fig. 3). Although EDTA caused some decrease in the turbidity of a suspension of the walls of $\boldsymbol{E}$. coli, no significant extraction of wall components occurred with $E$. coli (the same batch of walls) or with $\boldsymbol{P}$. mirabilis, and the infrared spectra were unaltered.

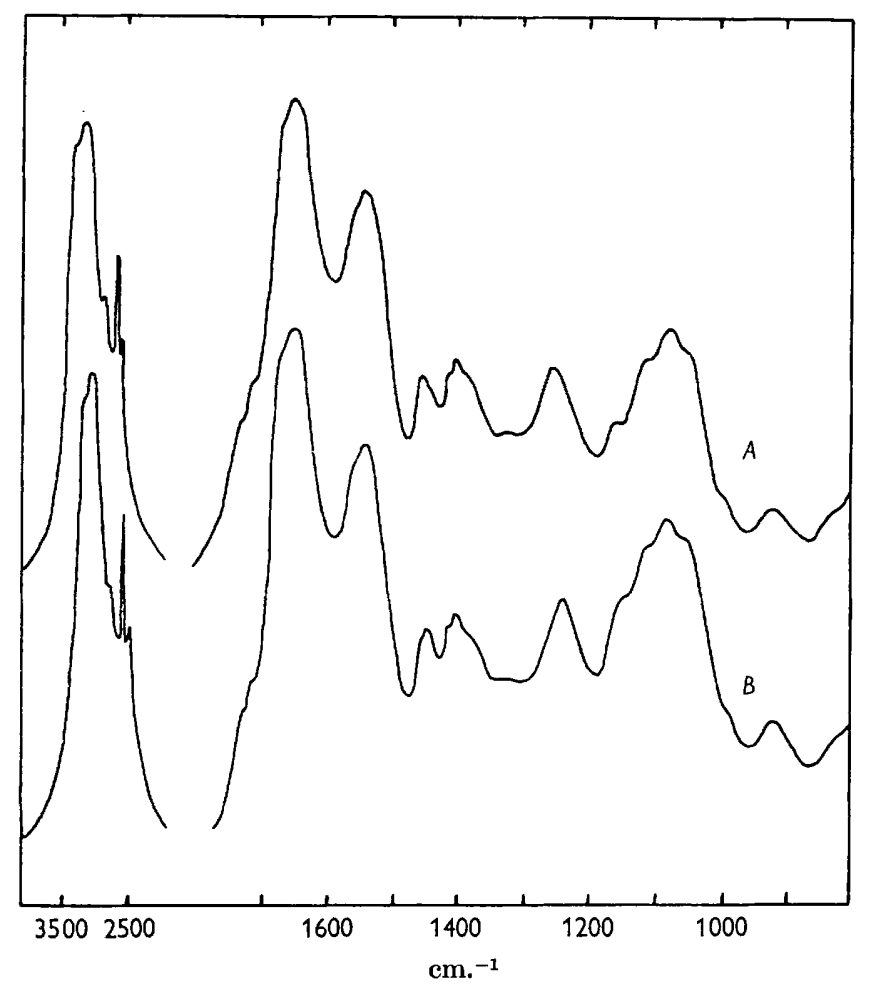

Fig. 4. The infrared spectrum of cell walls of Pseudomonas aeruginosa after treatment with EDTA. Cell walls were extracted for $1 \mathrm{hr}$ at 18-20 with 0.0034 M-EDTA in borate buffer pH $9 \cdot 2(A)$ or with buffer alone $(B)$.

\section{DISCUSSION}

The results of analyses on the cell walls from Pseudomonas aeruginosa, Alcaligenes faecalis, Escherichia coli and Proteus mirabilis reflect the complexity of these structures in Gram-negative bacteria and resemble those obtained by other workers, although some differences (e.g. in monosaccharide components) were noted. The walls contained appreciable amounts of protein, polysaccharide and lipid, but relatively little mucopeptide.

Although detailed knowledge of bacterial lipids is increasing, little information is yet available about the nature of the lipids which are localized in the cell walls of Gram-negative bacteria. The lipids of the cell wall are of two types, of which one is released only after mild acid hydrolysis (Salton, 1953; Westphal \& Lüderitz, 1954); only the readily extractable lipids are considered here. The lipids extracted from 
whole cells frequently contain a high proportion of phospholipids, and of phosphatidylethanolamine in particular (Asselineau, 1962; Kaneshiro \& Marr, 1962; Kanfer \& Kennedy, 1963; Kates, Adams \& Martin, 1964), while from limited studies the lipids of cell walls seem to be similarly constituted (Few, 1955; Cota-Robles, Marr \& Nilson, 1958; Wylie \& Johnson, 1962). Also peptido-lipids or lipid-amino acid complexes have been reported as components of ethanolamine-containing lipids from whole Pseudomonas aeruginosa (Silberman \& Gaby, 1961; Sinha \& Gaby, 1964) and Alcaligenes faecalis (Saito \& Akashi, 1957). The present results are similar to those cited above and confirm the predominance of phosphatidylethanolamine in the phospholipid fractions. It has also been shown that substantial amounts of free fatty acids were present in the walls of the bacteria grown as described. Free fatty acids do not appear to have been previously identified in cell-wall lipids, but the neutral fraction of whole-cell lipid from Escherichia coli has been reported to consist largely of free fatty acid (Kaneshiro \& Marr, 1962); similar reports have been made for other bacteria (O'Leary, 1962).

Although points of difference between the cell-wall lipids of organisms sensitive or resistant to EDTA have been noted, the most striking correlation between sensitivity to EDTA and composition of cell wall was found in the high phosphorus content and the similar monosaccharide components of the walls of sensitive organisms (Tables 1, 2). The significance of this observation was confirmed by the solubilization of phosphorus and carbohydrate components from cell walls of sensitive bacteria by EDTA. The cell walls of Pseudomonas aeruginosa and Alcaligenes faecalis appear to contain material not present or present only in small amounts firmly bound, in the walls of the more EDTA-resistant bacteria. Thus, the bactericidal activity of EDTA against the above organisms is probably to be explained by its action in solubilizing material essential to the integrity of their cell walls. Such an action is implicit in the claims of Campbell, Hogg \& Strasdine (1962) and Norton, Bulmer \& Sokatch (1963) to have prepared cell (protoplast) membranes of $\boldsymbol{P}$. aeruginosa by using lysozyme + EDTA. By contrast, the cell walls of other Gram-negative organisms are not completely removed by treatment with lysozyme +EDTA (Holme, Malmborg \& Cota-Robles, 1960; Murti, 1960; Salton, 1961).

Although the material extracted by EDTA in the present work has not yet been characterized, it seems likely to be lipopolysaccharide in nature. Thus, the extra phosphorus present in the walls of EDTA-sensitive organisms could not be accounted for by extractable phospholipid, and teichoic acids were not detected in wall preparations. The results of preliminary work done in these laboratories by $\mathrm{Dr}$ D. J. Byron and Mr J. W. Payne on material extracted by EDTA from the walls of Pseudomonas aeruginosa are strongly indicative of a lipopolysaccharide. Also, Homma, Suzuki \& Ito (1963) showed that a water-soluble lipopolysaccharide was released by EDTA+lysozyme from the 'bacterial surface substance' (probably cell wall +membrane) of a strain of $\boldsymbol{P}$. aeruginosa. The involvement of lipopolysaccharide rather than lipoprotein (Noller \& Hartsell, 1961 $a, b$ ) in the sensitization of Gram-negative bacteria to lysozyme by EDTA would be intelligible in view of the intimate association of lipopolysaccharide with mucopeptide (Weidel et al. 1960).

Although we assume that the action of EDTA involves metal cations present in the cell wall, it is not known whether the cations serve to bind lipopolysaccharide to 
other components of the walls (see Humphrey \& Vincent, 1962) or prevent release of lipopolysaccharide by inhibiting the action of autolytic enzymes which may be present in the walls. Calcium and magnesium have recently been detected in the lipid A component of lipopolysaccharides from Escherichia coli (Burton \& Carter, 1964).

The authors wish to thank the Directors of Reckitt and Sons Ltd., Hull, for financial support (to S. G. W.) and for providing facilities for bacteriological work. We also thank Mrs A. Strickland, who obtained the infrared spectra of bacterial fractions, and Dr R. M. Hinde and Mrs I. M. Honey of British Insulated Callender's Cables Ltd., who checked the purity of samples of bacterial cell walls by electron microscopy.

\section{REFERENCES}

Alleen, R. J. L. (1940). The estimation of phosphorus. Biochem. J. 34, 858.

Asselineau, J. (1962). Les lipides bactériens. Paris: Hermann.

Brown, A. D. (1958). An effect of drying the isolated cell walls of Streptococcus faecalis and a Pseudomonas species. Biochim. biophys. Acta, 28, 445.

Burton, A. J. \& CARTer, H. E. (1964). Purification and characterisation of the lipid A component of the lipopolysaccharides from Escherichia coli. Biochemistry, 3, 411.

Campbell, J. J. R., Hogg, L. A. \& Strasoine, G. A. (1962). Enzyme distribution in Pseudomonas aeruginosa. J. Bact. 83, 1155.

CoLOBERT, L. (1957 a). Inactivation par le lysozyme de l'antigène somatique de Salmonelles pathogènes chauffées. C.r. hebd. Séanc. Acad. Sci., Paris, 244, 2863.

Colobert, L. (1957 $b$ ). Destruction par le lysozyme, après délipidation de la paroi externe, de Salmonelles pathogènes. C.r. hebd. Séanc. Acad. Sci., Paris, 245, 1674.

Colobert, L. (1958). Étude de la lyse de Salmonelles pathogènes provoquée par le lysozyme, après délipidation partielle de la paroi externe. Ann. Inst. Pasteur, 95, 156.

Colobert, L. \& Creach, O. (1960). Obtention du substrat du lysozyme contenu dans la paroi ectoplasmique d'Eberthella typhi. Biochim. biophys. Acta, 40, 167.

Cota-Robles, E. H., Marr, A. G. \& Nilson, E. H. (1958). Submicroscopic particles in extracts of Azotobacter agilis. J. Bact. 75, 243.

Dische, Z. (1953). Qualitative and quantitative colorimetric determination of heptoses. J. biol. Chem. 204, 983.

FEw, A. V.(1955). The interaction of polymyxin $\mathrm{E}$ with bacterial and other lipids. Biochim. biophys. Acta, 16, 137.

Fischer, F. G. \& Nebel, H. J. (1955). Qualitative and quantitative estimation of glucosamine and galactosamine by the method of paper chromatography. Hoppe-Seyl. Z. 302, 10.

Gray, G. M. \& MacFarlane, M. G. (1958). Separation and composition of the phospholipids of ox heart. Biochem. J. 70, 409 .

Gray, G. W. \& Wilkinson, S. G. (1965). The action of ethylenediaminetetra-acetic acid on Pseudomonas aeruginosa. J. appl. Bact. 28, 153.

Grula, E. A. \& Hartsell, S. E. (1957). Lysozyme in the bacteriolysis of Gram-negative bacteria. II. Factors influencing clearing during the Nakamura treatment. Canad. J. Microbiol. 3, 23.

HaNES, C. S. (1929). An application of the method of Hagedorn and Jensen to the determination of larger quantities of reducing sugars. Biochem. J. 23, 99.

Herzberg, M. \& Green, J. H. (1964). Composition and characteristics of cell walls of smooth strains of Salmonella typhimurium and derived rough variants. J. gen. Microbiol. 35, 421.

Holme, T., Malmborg, A.-S. \& Cota-Robles, E. (1960). Antigens of spheroplast membrane preparations from Escherichia coli B. Nature, Lond. 185, 57. 
Homma, J. Y., Suzuki, N. \& Iтo, F. (1963). The surface structure of Pseudomonas aeruginosa. J. Immunol. 90, 819.

Humphrey, B. \& Vincent, J. M. (1962). Calcium in cell walls of Rhizobium trifolii. J. gen. Microbiol. 29, 557 .

JeRMYN, M. A. \& IsHerwood, F. A. (1949). Improved separation of sugars on the paper partition chromatogram. Biochem. J. 44, 402.

Kaneshino, T. \& Marr, A. G. (1962). Phospholipids of Azotobacter agilis, Agrobacterium tumefaciens, and Escherichia coli. J. Lipid Res. 3, 184.

Kanfer, J. \& Kennedy, E. P. (1963). Metabolism and function of bacterial lipids. I. Metabolism of phospholipids in Escherichia coli B. J. biol. Chem. 238, 2919.

Kates, M., Adams, G. A. \& Martin, S. M. (1964). Lipids of Serratia marcescens. Canad. J. Biochem. 42,461 .

Levine, C. \& Chargaff, E. (1951). Procedures for the microestimation of nitrogenous phosphatide constituents. J. biol. Chem. 192, 465.

Lis, E. W., Trnocq, J. \& Okex, R. (1961). A micromethod for fractionation of lipids by silicic acid chromatography. Analyt. Biochem. 2, 100.

Mandelstam, J. (1962). Preparation and properties of the mucopeptides of cell walls of Gram-negative bacteria. Biochem. J. 84, 294.

Marinetri, G. \& Stotz, E. (1954). Studies on the structure of sphingomyelin. IV. Configuration of the double bond in sphingomyelin and related lipids and a study of their infrared spectra. J. Amer. chem. Soc. 76, 1374.

Murt, C. R. K. (1960). Preparation of bacterial enzymes by controlled lysis. Biochim. biophys. Acta, 45, 243.

Noller, E. C. \& Hartsell, S. E. (1961 a). Bacteriolysis of Enterobacteriaceae. I. Lysis by four lytic systems utilising lysozyme. J. Bact. 81, 482.

Noller, E. C. \& Hartsell, S. E. (1961b). Bacteriolysis of Enterobacteriaceae. II. Preand co-lytic treatments potentiating the action of lysozyme. J. Bact. 81, 492 .

Norton, J. E., Burmer, G. S. \& Sokatch, J. R. (1963). The oxidation of D-alanine by cell membranes of Pseudomonas aeruginosa. Biochim. biophys. Acta, 78, 136.

O'Leary, W. M. (1962). The fatty acids of bacteria. Bact. Rev. 26, 421.

Rapport, M. M. \& Alonzo, N. (1955). Photometric determination of fatty acid ester groups in phospholipides. J. biol. Chem. 217, 193.

Repaske, R. (1956). Lysis of Gram-negative bacteria by lysozyme. Biochim. biophys. Acta, 22, 189.

REPASKe, R. (1958). Lysis of Gram-negative organisms and the role of Versene. Biochim. biophys. Acta, 30, 225.

Rhuland, L. E., Work, E., Denman, R. F. \& Hoare, D. S. (1955). The behaviour of the isomers of $\alpha, \epsilon$-diaminopimelic acid on paper chromatograms. J. Amer. chem. Soc. 77, 4844.

Rondle, C. J. M. \& Morgan, W. T. J. (1955). The determination of glucosamine and galactosamine. Biochem. J. 61, 586.

SaIto, K. \& Akashi, S. (1957). Lipide material of Alcaligenes faecalis. I. Studies on the acetone insoluble fraction by paper electrophoresis. J. Biochem., Tokyo, 44, 511.

Salton, M. R. J. (1953). Studies of the bacterial cell wall. IV. The composition of the cell walls of some Gram-positive and Gram-negative bacteria. Biochim. biophys. Acta, 10, 512.

Salton, M. R. J. (1958). The lysis of micro-organisms by lysozyme and related enzymes. J. gen. Microbiol. 18, 481.

Salton, M. R. J. (1960). Studies of the bacterial cell wall. VII. Monosaccharide constituents of the walls of Gram-negative bacteria. Biochim. biophys. Acta, 45, 364.

Salton, M. R. J. (1961). The anatomy of the bacterial surface. Bact. Rev. $25,77$.

Salton, M. R. J. \& Pavlik, J. G. (1960). Studies of the bacterial cell wall. VI. Wall composition and sensitivity to lysozyme. Biochim. biophys. Acta, 39, 398.

Silberman, R. \& Gaby, W. L. (1961). The uptake of amino acids by lipids of Pseudomonas aeruginosa. J. Lipid Res. $2,172$.

Sinha, D. B. \& GaBy, W. L. (1964). Structural composition of polar lipid-amino acid complex in Pseudomonas aeruginosa. J. biol. Chem. 239, 3668. 
Stacey, M. \& Barker, S. A. (1960). Polysaccharides of Micro-organisms, p. 62. Oxford University Press.

Stoffyn, P. J. \& Jeanloz, R. W. (1954). Hyaluronic acid and related substances. XII. Identification of amino sugars by paper chromatography. Arch. Biochem. 52, 373.

Trevelyan, W. E. \& Harrison, J. S. (1952). Studies on yeast metabolism. I. Fractionation and microdetermination of cell carbohydrates. Biochem. J. 50, 298.

Umbreit, W. W., Burris, R. H. \& Stauffer, J. F. (1957). Manometric Techniques, 3rd ed., p. 274. Minneapolis: Burgess Publishing Co.

Vincent, J. M. \& Humphrey, B. A. (1963). Partition of divalent cations between bacterial wall and cell contents. Nature, Lond. 199, 149.

WARDLAW, A. C. (1963). 'The complement-dependent bacteriolytic activity of normal human serum. II. Cell wall composition of sensitive and resistant strains. Canad. J. Microbiol. 9, 41.

Weidel, W., Frank, H. \& Martin, H. H. (1960). The rigid layer of the cell wall of Escherichia coli strain B. J. gen. Microbiol. 22, 158.

WestPhal, O. \& LüDERITZ, O. (1954). Chemische Erforschung von Lipopolysacchariden gramnegativer Bakterien. Angew. Chem. 66, 407.

WYure, E. B. \& Johnson, M. J. (1962). Effect of penicillin on the cell wall of Escherichia coli. Biochim. biophys. Acta, 59, 450. 